\title{
The Alvarado Score and Computed Tomography for Predicting Acute Appendicitis in Elderly Patients
}

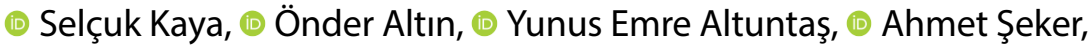 \\ (1) Levent Kaptanoğlu, (1) Nejdet Bildik, 이 Hasan Fehmi Küçük
}

Department of General Surgery, University of Health Sciences, Kartal Dr. Lütfi Kırdar Training and Research Hospital, İstanbul, Turkey

Submitted: 24.05 .2018 Accepted: 31.07 .2018

Correspondence: Selçuk Kaya, SBÜ Kartal Dr. Lütfi Kırdar Eğitim ve Araştırma Hastanesi, Genel Cerrahi Kliniği, İstanbul, Turkey E-mail: selcukkaya_36@hotmail.com

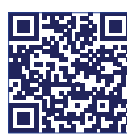

Keywords: Alvarado score; appendicitis in the elderly; computerized tomography.

\begin{abstract}
Objective: The aim of this study was to modify the Alvarado scoring system to increase its sensitivity and specificity in predicting acute appendicitis in elderly patients.

Methods: The data of 81 patients older than 70 years of age who were admitted for acute abdominal pain between January 2015 and December 2017 were randomized into 2 groups and evaluated retrospectively. In Group I patients, acute appendicitis was not histopathologically established postoperatively, while Group 2 patients had pathological results consistent with acute appendicitis. The sensitivity and specificity of computed tomography (CT) scans and Alvarado scores were evaluated in the 2 groups.
\end{abstract}

Results: The specificity and sensitivity of the modified Alvarado score was $86 \%$ and $81 \%$, respectively, whereas the specificity and sensitivity of a CT scan was $93 \%$ and $92.1 \%$, respectively, in diagnosing acute appendicitis.

Conclusion: There are a limited number of studies related to acute appendicitis in elderly patients and the current strategy for treatment is not clear. Due to the decreased sensitivity of the Alvarado score in the diagnosis of acute appendicitis in elderly patients, the goal of this research was to adjust the scoring system. Scores $>7$ are more reliable in predicting appendicitis. We believe that patients can be more accurately diagnosed in a short period of time using this modified Alvarado scoring system. In combination with a CT scan evaluation, the success rate of diagnosis may be improved and delayed diagnosis prevented.

\section{INTRODUCTION}

Acute appendicitis is the most common cause of acute abdominal surgery and its lifetime risk is $7 \% .^{\left[{ }^{[]}\right]}$Appendicitis is a disease of the young age group, which accounts only for $5 \%-10 \%$ of the acute causes of the elderly population. However, the incidence of disease in the elderly is increasing, possibly due to the increase in life expectancy. $[2,3]$ Perforated appendicitis constitutes approximately $20 \%$ of all appendicitis cases and significantly increases the rate of postoperative complications. ${ }^{[4]}$

Diagnosis of elderly patients with acute appendicitis is usually delayed, due to its atypical presentation and delay in admission to the hospital. Delay in diagnosis and treat- ment in the elderly causes an increase in perforation rates, thus worsening the clinical condition and an increase in morbidity and mortality. ${ }^{[5]}$ It has been reported that the perforation and morbidity rates are $70 \%$ and $48 \%$, respectively. ${ }^{[6]}$

Advance age is an independent high risk factor for surgery and anesthesia. ${ }^{[7,8]}$ For this reason, researchers are trying to develop management strategies tailored to the elderly population. The management strategy of acute appendicitis in the elderly is still uncertain and there are few studies in this regard. Clinically, evaluation of acute appendicitis requires systematic examination of symptoms, signs and diagnostic tests which reduces diagnostic errors. 
In 1986, Alfredo Alvarado developed a total 10-point scoring system, also known as the abbreviation of MANTRELS, based on symptoms, findings, and diagnostic tests for the diagnosis of acute appendicitis in patients who present with suspect acute appendicitis. ${ }^{[9]}$ According to this scoring system, it is recommended that the patients who have $\geq 7$ points should undergo surgery and those who have $<7$ points should be followed up. ${ }^{[9,10]}$

It has been reported that the use of the current interpretation of the Alvarado score in elderly patients will increase complications, mortality and morbidity in patients with acute appendicitis due to erroneous, and delayed diagnosis. ${ }^{[1]}$ When the probability of appendicitis is within the suspected range, then advanced examinations such as ultrasonography and computed tomography (CT) scan are recommended. ${ }^{\left[{ }^{[2]}\right]}$ In recent studies, the sensitivity and specificity of CT scans for acute apendicitis were found to be $87 \%-100 \%$ and $83 \%-98 \%$, respectively. ${ }^{[13]}$

By modifying Alvarado scoring system, we aimed to improve its sensitivity and specificity in the prediction of acute appendicitis in elderly patients.

\section{MATERIAL AND METHODS}

We performed a retrospective study between January 2015 and December 2017 with 81 patients over 70 years of age who were admitted to our clinic with acute abdominal pain. Forty-eight of $8 \mathrm{I}$ patients underwent appendectomy due to acute appendicitis, while the remaining 33 patients were discharged with medical treatment after observation or hospitalization.

The patients were divided into Group I that consisted of 38 patients who were discharged with medical treatment and whose pathologic diagnosis was incompatible with acute appendicitis. Group 2 comprised of 43 patients whose definite diagnosis was compatible with appendicitis based on histopathological examination.

Patient's examination findings, laboratory values and $\mathrm{CT}$ scan results were evaluated by compiling, and scanning the hospital database and file system. Pathology slides were re-examined. Some patients with acute appendicitis who achieved cure, and followed up with antibiotherapy were not operated and thus excluded from the study. ${ }^{[14]}$

In this study Alvarado scoring system was used as clinical scoring system (Table I). The patients were divided into subgroups with $1-6$ points and 7-10 points based on Alvarado scoring. At CT: Grade 0 indicated normal appendix, and Grade I suspect cases of acute appendicitis. These patients had not any remarkable CT findings suggesting inflammation. There was a slight increase in appendiceal diameter or findings of inflammation at its loge. The appendiceal diameter of these patients was normal or the
Table I. Components of the Alvarado score

\begin{tabular}{lc}
\hline Alvarado score & Score \\
\hline Leukocytosis $>10.000 / \mathrm{mm}^{3}$ & 2 \\
Tenderness in right lower quadrant & 2 \\
Migration of pain & $\mathrm{I}$ \\
Rebound pain & $\mathrm{I}$ \\
Elevated temperature $\left(>37.3^{\circ} \mathrm{C}\right)$ & $\mathrm{I}$ \\
Nausea & $\mathrm{I}$ \\
Anorexia & $\mathrm{I}$ \\
Neutrophilia $>65 \%$ & $\mathrm{I}$ \\
Total & 10
\end{tabular}

Scores: 1-4: Discharge 30\% appendicitis; 5-7: Monitoring/admission 66\% appendicitis; 8-10: Surgery $93 \%$ appendicitis.

presence of their appendices could not be revealed. Grade 2 indicates typical acute appendicitis; the findings of CT include dilation of appendiceal lumen, edematous thickening of the appendiceal wall, and contamination in lymph nodes in the surrounding fatty tissues and/or fatty tissue.

Grade 3 had CT findings of acute appendicitis associated with irregularity of the appendiceal wall and / or presence of intense nonreactive free fluid around it. When the results of CT were assessed, normal appendixes and suspect cases with acute appendicitis (Grade $0+$ Grade I) were included in Group I. The cases with CT findings evaluated as acute appendicitis (Grade $2+$ Grade 3 ) were included in Group 2. Sensitivity and specificity of CT and Alvarado scoring were assessed in patients older than 70 years. The ethics committee of our hospital approved the realization of this study.

\section{Statistical analysis}

Statistical analyses were performed in the SPSS 20 statistical program. Normally distributed data were analyzed by $t-$ tests. Data with non-normal distribution were defined by median and range and analyzed by Mann-Whitney $U$ test. Relationships between the variables in the cross- tables were analyzed, if necessary, using square test or Fisher's test. Normality of data was analyzed using KolmogorovSmirnov test.

\section{RESULTS}

Forty-six (56.7\%) female and 35 (43.3\%) male patients (total $n=8 I$ ) aged 70 years or older presented to our clinic with acute abdominal pain. The mean age of the patients in Group I who were not reported as appendicitis based on histopathological evaluation of the appendectomy specimen and discharged with medical treatment without reoperation was $79.16( \pm 7.13)$ years, whereas the mean age 
Table 2. Demographic characteristics of patients, Alvarado scores and CT findings

\begin{tabular}{lccccr}
\hline & \multicolumn{2}{c}{ Negative } & & \multicolumn{2}{c}{ Pozitive } \\
\cline { 2 - 3 } \cline { 5 - 6 } & $\mathbf{n}$ & $\%$ & & $\mathbf{n}$ & $\%$ \\
\hline $\begin{array}{l}\text { Alvarado score } \\
\text { I-6 }\end{array}$ & 31 & 81.6 & & 14.0 \\
7-10 & 7 & 18.4 & & 37 & 86.0 \\
Computed tomography & & & & \\
$\quad 0-1$ & 35 & 92.1 & & 3 & 7.0 \\
$2-3$ & 3 & 7.9 & & 40 & 93.0 \\
Age & 79.16 & $( \pm 7.13)$ & & 76.56 & $( \pm 5.56)$ \\
Gender & & & & \\
$\quad$ Female & 21 & 55.3 & & 25 & 58.1 \\
$\quad$ Male & 17 & 44.7 & & 18 & 41.9 \\
\hline
\end{tabular}

Table 3. Proposed changes in the interpretation of the Alvarado scores for elderly

\begin{tabular}{lc}
\hline Alvarado scoring system & Our modified interpretation \\
\hline $1-4$ low risk & $1-6$ low risk \\
$5-6$ intermediate risk & $7-10$ high risk \\
$7-10$ high risk & \\
\hline
\end{tabular}

of the patients in Group 2 who were evaluated as acute appendicitis by pathological evaluation was $76.56( \pm 5.56)$ years. There were 38 patients in Group I and 43 patients in Group 2.

Five patients in Group I were treated with acute appendicitis but their pathologic diagnosis was incompatible with appendicitis. Our negative appendectomy rate was $10.4 \%$ According to the Alvarado scoring system, $37 \mathrm{pa}-$ tients received scores ranging from I to 6 points, while 44 patients had scores ranging from 7 to 10 points. According to these CT findings, 38 Grade $0-1$ and 43 Grade 2-3 patients were included in the study (Table 2 ).

In our study, the specificity, and sensitivity of Alvarado scores in establishing the diagnosis of acute appendicitis were $81 \%$, and $86 \%$, respectively. In our study, the specificity and sensitivity of CT findings in establishing the diagnosis of acute appendicitis were $93 \%$ and $92.1 \%$, respectively.

\section{DISCUSSION}

It is known that as the elderly population in the society increases, the number of patients who will present with acute abdominal pain will increase. The proportion of elderly patients diagnosed with acute appendicitis is esti- mated to increase in proportion to the number of patients treated.

In many studies mortality and morbidity rates increased in the elderly population due to delays in diagnosis. ${ }^{[3,15]}$ Therefore, elderly patients require accurate and prompt diagnosis of acute appendicitis. In many studies, acute appendicitis has been reported to have a higher incidence in women than in men. ${ }^{[16,17]}$ In our study, female / male ratio was $56.7 \%$ / $43.3 \%$. Lucas and colleagues found $83.3 \%$ false negatives and $45.5 \%$ false positives in scores of $\leq 5$ according to the Alvarado scoring system in the diagnosis of acute appendicitis in patients aged $60-80$ years. ${ }^{[18]}$ Some authors have suggested that acute appendicitis should be completely excluded in scores of $\leq 5$ in the Alvarado scoring system. ${ }^{[19]}$ In their interpretation of the general population using the classical Alvarado scoring system, rates of suspect cases with acute appendicitis in patients with scores $1-4,5-7$, and $8-10$ points were reported as $30 \%$, $66 \%$, and $93 \%$, respectively. ${ }^{[9]}$ The use of the current interpretation of the Alvarado scores in elderly patients has been reported to increase complications, mortality and morbidity rates in patients with acute appendicitis due to false and delayed diagnosis. ${ }^{[I]}$

In our study, we also modified the Alvarado scoring system in two groups of $1-6$ and 7-10 scores to minimize delay in diagnosis, complications, mortality and morbidity rates (Table 3). In our study, we determined the diagnostic value of the Alvarado scoring system with a higher accuracy, in patients who had a score of $1-6$ points, which established diagnosis, and those with a score of $7-10$ points that excluded acute appendicitis.

Alvarado score as $81.6 \%$ and $86 \%$, respectively. In the diagnosis of acute appendicitis sensitivity of CT has been reported to be $95 \%-100 \%$ for the general population, while in some studies it has been demonstrated as $81.6 \%$ for the elderly population. ${ }^{[1,20,21]}$ In our study, the specificity, and sensitivity of CT in the diagnosis of acute appendicitis were $93 \%$ and $92.1 \%$, respectively.

\section{CONCLUSION}

Since Alvarado scoring system has a lower diagnostic accuracy in elderly patients, we think that by modifying the Alvarado scoring system the diagnosis of acute appendicitis in elderly patients who score $\geq 7$ can be made in a timely manner with a higher diagnostic accuracy rate When the Alvarado scoring system is combined with CT in the diagnosis of acute appendicitis, we believe that the diagnostic success will increase and the diagnostic delays will decrease.

Ethics Committee Approval

Approved by the local ethics committee. 


\section{Informed Consent}

\section{Retrospective study.}

Peer-review

Internally peer-reviewed.

Authorship Contributions

Concept: S.K., Ö.A.; Design: S.K., Ö.A., Y.E.A.; Data collection \&/or processing: S.K., Ö.A.; Analysis and/or interpretation: S.K., Y.E.A., A.Ş.; Literature search: S.K., Y.E.A., A.Ş.; Writing: S.K., Ö.A., Y.E.A.; Critical review: H.F.K, N.B.

Conflict of Interest

None declared.

\section{REFERENCES}

1. Ergul E. Importance of family history and genetics for the prediction of acute appendicitis. The Internet Journal of Surgery 2006;10:1-4.

2. Horattas MC, Guyton DP, Wu D. A reappraisal of appendicitis in the elderly. Am J Surg 1990;160:291-3. [CrossRef]

3. Storm-Dickerson TL, Horattas MC. What have we learned over the past 20 years about appendicitis in the elderly? Am J Surg 2003;185:198-201. [CrossRef]

4. Butler C. Surgical pathology of acute appendicitis. Human pathology 1981;12:870-8. [CrossRef]

5. Franz MG, Norman J, Fabri PJ. Increased morbidity of appendicitis with advancing age. Am Surg 1995;61:40-4.

6. Wilcox RT, Traverso LW. Have the evaluation and treatment of acute appendicitis changed with new technology? Surg Clin North Am 1997;77:1355-70. [CrossRef]

7. Hamel MB, Henderson WG, Khuri SF, Daley J. Surgical outcomes for patients aged 80 and older: morbidity and mortality from major noncardiac surgery. J Am Geriatr Soc 2005;53:424-9. [CrossRef]

8. Bentrem DJ, Cohen ME, Hynes DM, Ko CY, Bilimoria KY. Identification of specific quality improvement opportunities for the elderly undergoing gastrointestinal surgery. Arch Surg 2009;144:1013-20.
9. Alvarado A. A practical score for the early diagnosis of acute appendicitis. Ann Emerg Med 1986;15:557-64. [CrossRef]

10. Nirajlal B, Gabriel R, Anand R, Sohil AK. Evaluation of Alvarado score in acute appendicitis: A prospective study. The Internet Journal of Surgery 2007;9.

11. Shchatsko A, Brown R, Reid T, Adams S, Alger A, Charles A. The utility of the Alvarado score in the diagnosis of acute appendicitis in the elderly. Am Surg 2017;83:793-8.

12. Terasawa T, Blackmore CC, Bent S, Kohlwes RJ. Systematic review: computed tomography and ultrasonography to detect acute appendicitis in adults and adolescents. Ann Intern Med 2004;141:537-46.

13. Addiss DG, Shaffer N, Fowler BS, Tauxe RV. The epidemiology of appendicitis and appendectomy in the United States. Am J Epidimiol 1990;132:910-25. [CrossRef]

14. Turhan AN, Kapan S, Kütükçü E, Yiğitbaş H, Hatipoğlu S, Aygün E. Comparison of operative and non operative management of acute appendicitis. Ulus Travma Acil Cerrahi Derg 2009;15:459-62.

15. Gurleyik G, Gurleyik E. Age-related clinical features in older patients with acute appendicitis. Eur J Emerg Med 2003;10:200-3. [CrossRef]

16. Blomqvist PG, Andersson RE, Granath F, Lambe MP, Ekbom AR. Mortality after appendectomy in Sweden, 1987-1996. Ann Surg 2001;233:455-60. [CrossRef]

17. Addiss DG, Shaffer N, Fowler BS, Tauxe RV. The epidemiology of appendicitis and appendectomy in the United States. Am J Epidimiol 1990;132:910-25. [CrossRef]

18. Gwynn LK. The diagnosis of acute appendicitis: clinical assessment versus computed tomography evaluation. J Emerg Med 2001;21:119. 23. [CrossRef]

19. Ohle R, O'Reilly F, O'Brien KK, Fahey T, Dimitrov BD. The Alvarado score for predicting acute appendicitis: a systematic review. BMC Med 2011;9:139. [CrossRef]

20. Gwynn LK. The diagnosis of acute appendicitis: clinical assessment versus computed tomography evaluation. J Emerg Med 2001;21:119-23.

21. Dahabreh IJ, Adam GP, Halladay CW, Steele DW, Daiello LA, Wieland LS, et al. Diagnosis of right lower quadrant pain and suspected acute appendicitis. Rockville: Agency for Healthcare Research and Quality; 2015.

\section{Yaşlı Hastalarda Akut Apandisit Tahmini İçin Alvarado Skoru ve Bilgisayarlı Tomografi}

Amaç: Yaşlı hastalarda akut apandisitin tahmininde Alvarado skorlama sistemini modifiye ederek, skorlamanın sensivite ve spesifitesini arttırmayı amaçladık.

Gereç ve Yöntem: Ocak 20I5-Aralık 2017 tarihleri arasında kliniğimizde akut karın ağrısı ile başvuran yetmiş yaş üstü $8 \mathrm{I}$ hastanın dahil edildiği geriye dönük bir çalışma yürüttük. Tıbbi takiple taburcu edilen ve ameliyat sonrası patolojik tanısı apandisit ile uyumlu olmayan hastalar Grup I, ameliyat sonrası histopatolojik olarak apandisit olduğu gösterilmiş hastalar Grup 2 olarak tanımlandı. Bilgisayarlı tomografi (BT) ve Alvarado skorunun yetmiş yaş üstü hastalarda sensivitesi ve spesifitesi değerlendirildi.

Bulgular: Çalışmamızda, modifiye Alvarado skorunun akut apandisit tanısını koymada spesifitesi \%8I, sensitivitesi \%86 iken BT'nin spesifitesi \%93, sensitivitesi \%92.I olarak bulunmuştur.

Sonuç: Yaşlılarda akut apandisite yönelik stratejisi hala belirsizdir ve bu konuda az sayıda çalışma vardır. Alvarado skorlama sisteminin yaşlı hastalarda tanıda duyarlılı̆ııın düşük olduğundan dolayı, Alvarado skorlama sistemini modifiye ederek 7 ve üzerinde skor alan yaşlı hastalarda akut apandisit tanısının daha yüksek doğrululuk oranıyla, zamanında teşhis edilebileceğini düşünmekteyiz. Akut apandisit tanısında Alvarado skorlama sistemi ile BT kombine edildiğinde tanıdaki başarının artıp teşhisteki gecikmenin azalacağı kanaatindeyiz.

Anahtar Sözcükler: Alvarado skoru; bilgisayarlı tomografi; yaşlılarda apandisit. 